\title{
中耳圧変化の聴覚に及ぼす影響
}

一螖電図学的研究一

花田誠

\section{Electrocochleographic Study of Effect of Middle Ear Pressure Change on Hearing}

\author{
Makoto Hanada \\ (Shiga University of Medical Science)
}

Middle ear pressure changes have been thought to cause sensori-neural loss as well as conductive hearing loss. To clarify the degree and mechanism, we used electrocochleography in guinea pigs to investigate electrophysiological changes in the inner ear while positive or negative pressure changes were applied only to the middle ear cavity (middle ear group), or to the external auditory canal and middle ear cavity simultaneously (external-middle ear group).

1) Significant reductions in action potential (AP) amplitude were found in the middle ear group receiving either positive or negative pressure, but there was no significant difference between the two groups. No significant reductions were found in the external-middle ear group regardless of whether positive or negative pressure was applied.

2) Significant reductions in summating potential (SP) amplitude and SP/AP ratio were found in the middle ear group receiving positive pressure. There was wide variation in the changes observed in the middle ear group receiving negative pressure. The external-middle ear group receiving negative pressure showed greater reductions in SP amplitude and SP/AP ratio than the group receiving positive pressure, implying a difference in the changes in stiffness of the inner ear windows between the two groups.

3) Rebound phenomenon in SP amplitude and SP/AP ratio was found in the middle ear group when positive pressure in the middle ear cavity was released, implying secondary effects on hearing due to inner ear pressure changes.

Key words : middle ear pressure change, electrocochleography, hearing

\author{
緒言 \\ 近年, 飛行・潜水等によって生じる気圧变化に伴う聴 \\ 平衡器の障害(中・内耳圧外傷) 関する様々の報告がな \\ されている1) 4)。 また，我々の日常生活においてこのよ \\ らな圧外傷を生じるような大きな圧变化に曝露されなく \\ てもより小さな圧変化には曝露される機会は数多く存在 \\ する5)。このような場合，耳管による鼓膜内外の圧不均
}

衡が是正されなければ中耳圧変化が生じ, 中・内耳機能 に影響を及汸し聴平衡覚に変化が生じる. 中耳圧変化の聴覚に与える影響については, Fowler ${ }^{6)}$ がヒトで耳管から中耳に圧を負荷すると気導聴力のみな らず骨導聴力にも閾值の上昇がみられることを報告して 以来, 数多くの報告がなされている.

Loch? ${ }^{7}$ は, ヒトに扔いてバルサルバ法により中耳に 
陽圧・陰圧負荷を与えた時の聴力閾値に対する影響を調 べた結果，陽圧負荷と陰圧負荷の場合では聴力低下のパ ターンが異なることを認めた． Kobrak ${ }^{8)}$ はウサギとイ 又を用いて中耳压を変化させた時の聴力変化を鼓膜張筋 反射の観察によって測定し, 中等度中耳圧変化 ( 80 $\left.\mathrm{mmH}_{2} \mathrm{O}\right)$ までは大きな聴力変化は生じず, 高度中耳圧 変化 $\left(264 \mathrm{mmH}_{2} \mathrm{O}\right)$ 飞括いて陽・陰圧とも聴力低下が認 められたことを報告した。 また, Wever ら910)はネコに おいて中耳に陽圧・陰圧負荷を与兄た時の気導拉よび骨 導刺激に対する蝸牛マイクロホン電位 $(\mathrm{CM})$ を正円空上 り測定し, 気導・骨導とも陽圧・陰圧負荷間 $($ 最大 \pm 660 $\left.\mathrm{mmH}_{2} \mathrm{O}\right)$ ではほぼ同程度の反応低下を認めたが個体差 がありまた気導と骨導では異なった反応低下のパター ンを示すことを認めた。これに対し McPherson ら ${ }^{11)}$ は モルモットに拈いてやはり中耳压負荷時 (最大 \pm 500 $\left.\mathrm{mmH}_{2} \mathrm{O}\right)$ の $\mathrm{CM}$ を正円空上り測定し, 陽・陰圧負荷間 では陰圧負荷の方が反応低下が大きい傾向にある (asymmetrical effect と称している) としている.このように, 中耳厈変化が単独に生じた場合の陽・陰圧変化による聴 覚の変化の違いやその程度についてはいまだ見解の分か れるところである.

他方に, 外耳圧と中耳圧の変化が同時に生じた場合の 聴覚变化に関するいくつかの報告もある. Rahm ら ${ }^{12)}$ はネコに招いて外・中耳同時に陽・陰圧負荷を行った時 の気導刺激に対する $\mathrm{CM}$ を正円空より測定したところ, \pm 4 inches $\mathrm{H}_{2} \mathrm{O}\left( \pm 102 \mathrm{mmH}_{2} \mathrm{O}\right)$ の圧負荷では特に変化 を認めず， \pm 20 inches $\mathrm{H}_{2} \mathrm{O}\left( \pm 508 \mathrm{mmH}_{2} \mathrm{O}\right)$ の圧負荷で は(個体差が大きく圧負荷問題がある可能性に言及し ているものの) $8 \mathrm{~dB}$ の反応低下を認めたとしている.

Ohmura ら ${ }^{13)}$ はモルモットに拈いて外・中耳同時圧負 荷時 (最大 $\pm 528 \mathrm{mmH}_{2} \mathrm{O}$ ) の $\mathrm{CM}$ を測定し, 陽圧負荷で は有意な反応低下を認めなかったが陰圧負荷では有意な 反応低下を認めたと報告している。これらの報告は, 鼓 膜内外の圧不均衡が是正されている場合でも中耳圧变化 が生じると聴力低下が生じる可能性があることを示唆し ているが，その機序は不明である。

また，外・中耳圧変化が平衡機能に変化をきたし内耳 への影響を示唆する報告14115) もあり，この現象は内リ

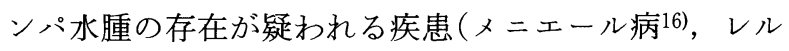
モワイエ症候群17), 先天性梅毒18) 等) で多く認められ仮 性㾇孔症状として知られている.

一方, 蝸電図は内耳の電気生理学的変化を知る手段と
して極めて有用で，他覚的聴覚検査㧍よび内リンパ水腫 存在の有無検索に広く利用されている. 特に内リンパ水 腫存在の有無検索の場合蝸電図波形 (SP/AP 比) が問題 となり，上記のように中耳圧变化が中・内耳に影響を及 ぼすのならば蝸電図波形にも少なからず変化が生じるは ずであるが，外・中耳圧変化と蝸電図波形 $(\mathrm{SP} \cdot \mathrm{AP}$ 複 合波形)の関係を調べた報告はそしく，ただ Ferraro ら ${ }^{19)}$ の報告をみるのみである。彼らは正常人において 外耳圧負荷 (最大 $\pm 300 \mathrm{mmH}_{2} \mathrm{O}$ ) を与えた時の $\mathrm{SP} \cdot \mathrm{AP}$ 複合波形を鼓室外誘導にて記録したところ，陽・陰圧負 荷によって共に SP/AP 比の有意な増加を認めたと述べ ているが，外耳のみに圧負荷を行っているため SP • $\mathrm{AP}$ 複合波形の変化が中耳圧変化の久泣よるものがう かについては疑問が残る.

そこで本研究では, 測定が簡便かつ非侵襲的であり聴 覚機能検査としての意義がほ济確立されているため現在 臨床的に頻用されている SP・AP 複合波形を指標とし て, (1)中耳圧変化が単独に生じた場合, 陽・陰圧变化に よる聴覚の変化の様式やその程度に差があるのかどうか (2)外耳圧と中耳圧が同時に変化した場合, 聴覚の变化が 生じるのかどらか(3)臨床上問題となる $\mathrm{SP} \cdot \mathrm{AP}$ 複合波 形の変化が中耳圧変化によって生じるのかどらか, 等の 点を明らかにする目的で, 正常モルモットを用いて中耳 圧負荷(陽・陰圧)を行なったときの蝸電図を記録し，中 耳圧変化の聴覚拉よび蝸電図波形 $(\mathrm{SP} \cdot \mathrm{AP}$ 複合波形 $)$ に及汭す影響について調べ検討した。

\section{方法}

実験動物はプライエル耳介反射正常なハートレイ系モ ルモット35匹（体重 300～600 g)を使用した。ペントバ ルビタール $(30 \mathrm{mg} / \mathrm{kg})$ 腹腔内注射による全身麻酔下に 気管切開を施行した後, 塩化ツボクラリン $(1 \mathrm{mg} / \mathrm{kg})$ で 不動化し, 人工呼吸器にて呼吸管理を行なった。

先ず動物を腹臥位に固定し，右耳介を切断後右耳後部 を切開, 乳突部骨胞を露出した。ここに径 $3 \mathrm{~mm}$ の小孔 をあけ中耳圧負荷用シリコンチューブを挿入し歯科用セ メントとエポキシ系接着剤にて固定した.このチューブ は压負荷装置 (DANA Japan 製) に接続した。また，右 外耳道骨部には音刺激用および外耳圧負荷用シリコンチ ューブを挿入し歯科用セメントとエポキシ系接着剤にて 固定した. 次に，動物を背臤位に固定し，右下䫇内側に 皮切を加光，右中耳骨胞を露出した，骨胞に小孔を穿ち 
耳管豉室口和よび蝸牛全回転を明視下に扮き，歯科用七 メントにて耳管鼓室口を閉鎖した。また，銀ボール電極 を固定したガラスキャピラリーをマイクロマニュプレー ターで蝸牛基底回転前庭階骨壁に密着させた，その後， 小孔を歯科用セメントにて air tightに再び閉鎖した。 不 関電極は頸笳に招き，音刺激は $90 \mu \mathrm{sec}$ square clickを 用い，三栄製音刺激用イアホーンを外耳道に挿入したシ リコンチューブに固定し closed method で与え，最大音 圧は臨床蝸電図との対応より $105 \mathrm{~dB}$ pe SPL とした。 （音圧較正は体重の異なる数匹の動物より作製した外耳 道模型により行なった。）

蝸牛電位の測定は三栄製 7S-11 signal processor を用 い, 加算回数 16 回, 刺激間隔 $125 \mathrm{msec}$, 解析時間 20 msec, Low cut filter $8 \mathrm{~Hz}$, High cut filter $4 \mathrm{kHz}$ とした. 中耳圧および外耳圧負荷は，圧負荷装置により原則と して $\pm 300 \mathrm{mmH}_{2} \mathrm{O}$ 負荷を行なった(予備実験の結果よ り蝸牛電位に明らかな変化を生じる最小の圧負荷として $\pm 300 \mathrm{mmH}_{2} \mathrm{O}$ を用いたが一部の動物では $\pm 500 \mathrm{mmH}_{2} \mathrm{O}$ を用いた）。すなわち，最初の 6 秒間で中耳厈および外 耳圧を $\pm 50 \mathrm{mmH}_{2} \mathrm{O} / \mathrm{sec}$ の速度で $\pm 300 \mathrm{mmH}_{2} \mathrm{O}$ に変 化させ, 蝸牛電位測定終了後まで一定に保ち, 測定終了 後上記の速度で中耳圧および外耳圧負荷を解除し, 解除 終了直後再び蝸牛電位を測定した．音刺激は中耳圧・外 耳圧変化直後敊よび圧負荷解除直後に与元て蝸牛電位を 記録し, 得られた $\mathrm{SP} \cdot \mathrm{AP}$ 複合波形より AP 振幅, SP 振幅, SP/AP 比\%を測定した。AP振幅预よび SP 振 幅は基線からの高さとして計測した（図 1)。圧負荷に関 しては，前の圧負荷による影響を避けるために 1 個体に ついては 1 種類の圧負荷を 1 回のみ行い，上記のパラ メーターを測定した，また，中耳骨胞に対する処置およ び測定中中耳腔内に生じる渗出液等の影響を検討するた めに圧負荷動物と同様の処置を施し圧負荷なしで蝸牛電 位を測定した動物をコントロールとして用いた。な执， コントロール群・圧負荷群ともに蝸牛電位測定終了後中 耳腔内を顕微鏡下にて観察し，明らかに渗出液眝留を認

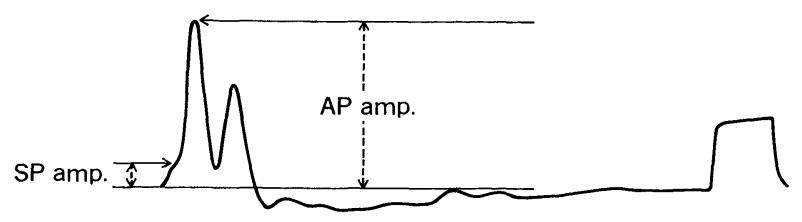

図 $1 \mathrm{AP} \cdot \mathrm{SP}$ 振幅の定義
めたものは除外した.

実験のブロックダイヤグラムを示す(図 2 ).

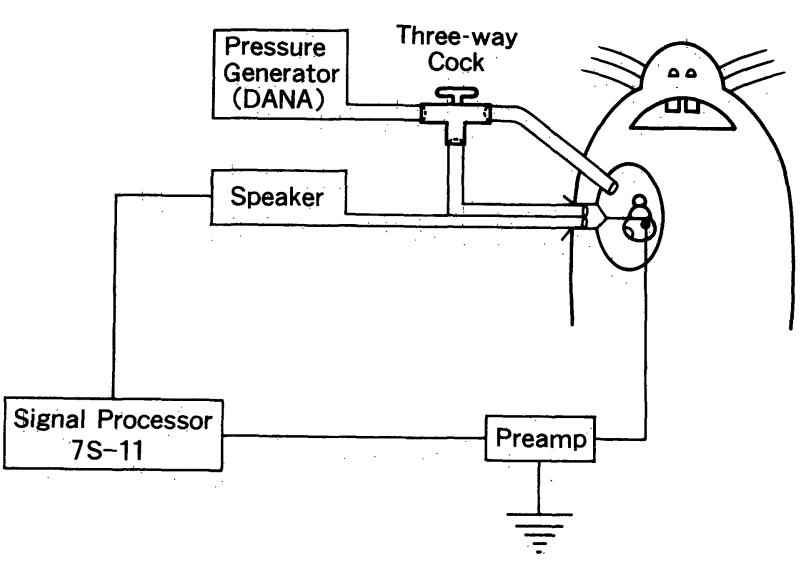

図 2 実験装置の block diagram

\section{結＼cjkstart果}

中耳圧抽よ゙中・外耳圧負荷による AP 振幅 (APamp.), SP 振幅 (SPamp.), SP/AP 比\% (SPamp. / APamp. $\times$ 100\%)の変化を評価するために測定値の相対変化率 (relative) 执よび絶対変化量 (absolute)を求めた.

相対変化率は

$$
\frac{\text { 圧負荷後の測定値 }}{\text { 圧負荷前の測定値 }} \times 100(\%)
$$

絶対変化量は

圧負荷前の測定値一圧負荷後の測定値

で定義される．AP 振幅特よび SP 振幅の評価には相対 変化率 (relative), SP/AP 比\%の評価には絶対変化量 (absolute)を用い，Wilcoxon 検定によって統計学的に 解析した.

(1) AP 振幅 (図 3 )

コントロール群, 中耳陽圧負荷群 $\left(+300 \mathrm{mmH}_{2} \mathrm{O}\right)$, 中 耳陰圧負荷群 $\left(-300 \mathrm{mmH}_{2} \mathrm{O}\right)$ の変化率はそれぞれ $98 \pm$ 4\% (n=9), $90 \pm 5 \%(n=9), 86 \pm 13 \%(n=7)$ であり，コ ントロール群に比し中耳負荷群は陽・陰圧共に有意に減 少した (陽圧 : $p<0.01$, 陰圧 : p < 0.05). 陽・陰圧負荷 群間では有意な差は認められなかったが陰圧負荷群の方 がより大さな減少傾向を認めた. 外・中耳陽圧負荷群 $\left(+300 \mathrm{mmH}_{2} \mathrm{O}\right)$, 外 - 中耳陰圧負荷群 $\left(-300 \mathrm{mmH}_{2} \mathrm{O}\right)$ 


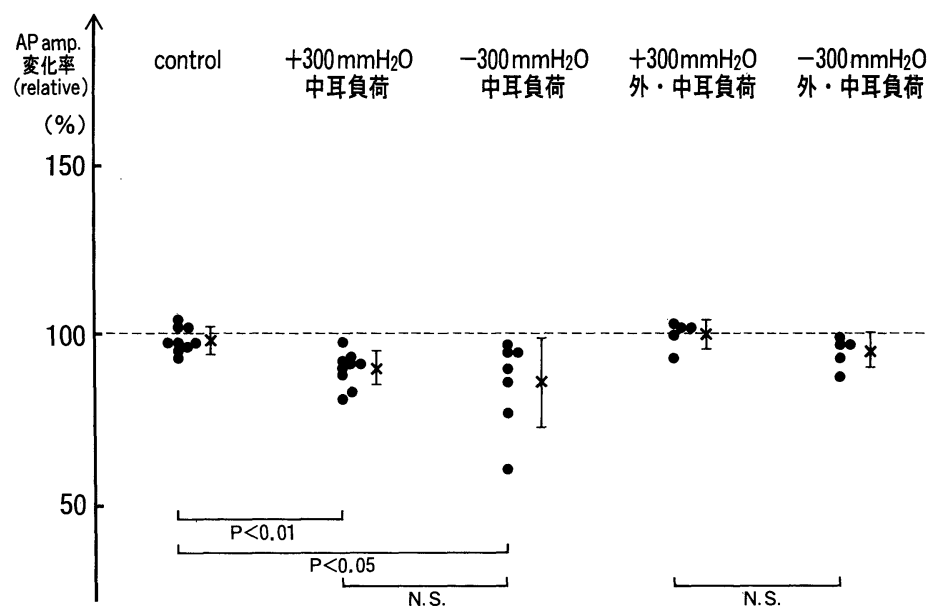

図 3 中耳拈よび外・中耳圧負荷時 $\left( \pm 300 \mathrm{~mm} \mathrm{H} \mathrm{H}_{2} \mathrm{O}\right)$ の $\mathrm{AP}$ 振幅変化率

の変化率はそれぞれ $100 \pm 4 \%(\mathrm{n}=5), \quad 95 \pm 5 \%(\mathrm{n}=5)$ で あり, コントロール群に比し陽・陰圧負荷群共有意な差 はなく, 陽・陰圧負荷群間にも有意な差は認められなか ったが陰圧負荷群の方に陽圧負荷群上りやや減少傾向を 認めた。

(2) SP 振幅 (図 4)

コントロール群, 中耳陽圧負荷群 $\left(+300 \mathrm{mmH}_{2} \mathrm{O}\right)$, 中 耳陰圧負荷群 $\left(-300 \mathrm{mmH}_{2} \mathrm{O}\right)$ の変化率はそれぞれ $94 \pm$ $7 \%(\mathrm{n}=9), 75 \pm 12 \%(\mathrm{n}=9), 85 \pm 26 \%(\mathrm{n}=7)$ であり, コ ントロール群に比し中耳負荷群では陽圧負荷において有 意な減少を認めた $(\mathrm{p}<0.01)$. 陰圧負荷においては測定 値のばらつきが大きくコントロール群怙よび陽圧負荷と
の間に有意な差を認めなかったが，圧負荷後振幅が増加 する例を 2 例認めた. 外 - 中耳陽圧負荷群 $\left(+300 \mathrm{mmH}_{2} \mathrm{O}\right)$, 外・中耳陰圧負荷群 $\left(-300 \mathrm{mmH}_{2} \mathrm{O}\right)$ の変化率はそれぞ れ $98 \pm 12 \%(\mathrm{n}=5), 73 \pm 5 \%(\mathrm{n}=5)$ であり，コントロー 儿群に比し陰圧負荷に执いてのみ有意な減少を認めた $(\mathrm{p}<0.05)$. また陽・陰圧負荷間では陰圧負荷において 陽圧負荷に比し有意な減少を認めた $(\mathrm{p}<0.05)$.

(3) SP/AP 比\% (図 5 )

コントロール群, 中耳陽圧負荷群 $\left(+300 \mathrm{mmH}_{2} \mathrm{O}\right)$, 中耳陰圧負荷群 $\left(-300 \mathrm{mmH}_{2} \mathrm{O}\right)$ の変化量はそれぞれ 一 $0.8 \pm 1.5 \%(\mathrm{n}=9), \quad-4.1 \pm 2.8 \%(\mathrm{n}=9), \quad-1.4 \pm 4.4 \%$ $(\mathrm{n}=7)$ であり, コントロール群に比し中耳負荷群では陽

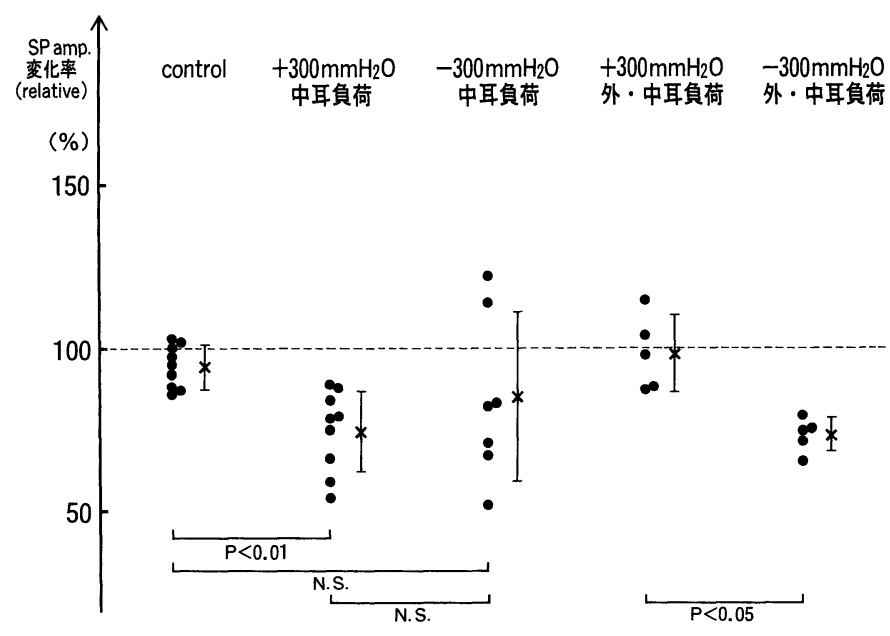

図 4 中耳括よび外・中耳圧負荷時 $\left( \pm 300 \mathrm{~mm} \mathrm{H}_{2} \mathrm{O}\right)$ の $\mathrm{SP}$ 振幅変化率 


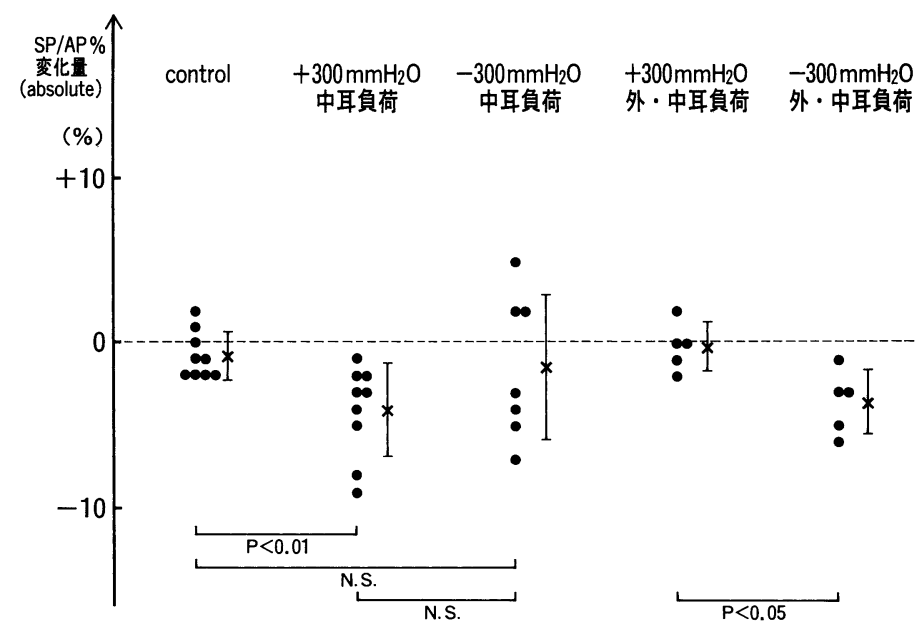

図 5 中耳执よび外・中耳圧負荷時 $\left( \pm 300 \mathrm{~mm} \mathrm{H}_{2} \mathrm{O}\right)$ の SP/AP 比 \%変化量

圧負荷に执いて有意な減少を認めた $(\mathrm{p}<0.01)$. 陰圧負 荷に括いてはSP 振幅の場合と同様に測定值のばらつき が大きくコントロール群打よび陽圧負荷との間に有意な 差を認めなかったが，圧負荷後 SP/AP 比\%が増加する 例を 3 例認めた. 外・中耳陽圧負荷群 $\left(+300 \mathrm{mmH}_{2} \mathrm{O}\right)$, 外・中耳陰圧負荷群 $\left(-300 \mathrm{mmH}_{2} \mathrm{O}\right)$ の変化量はそれぞ れ $-0.2 \pm 1.5 \%(\mathrm{n}=5), \quad-3.6 \pm 1.9 \%(\mathrm{n}=5)$ であり, コントロール群に比し陰圧負荷に执いてのみ有意な減少 を認めた $(\mathrm{p}<0.05)$. また陽・陰圧負荷間では陰圧負荷 に扣いて陽圧負荷に比し有意な減少を認めた $(\mathrm{p}<0.05)$.

（4）圧解除直後の AP 振幅，SP 振幅， SP/AP 比\% 中耳陽圧負荷群 $\left(+300 \mathrm{mmH}_{2} \mathrm{O}\right)$ 飞拈いて, 圧解除後
$\mathrm{AP}$ 振幅は全例注ぼ圧負荷前と同じレベルに戻ったが, $\mathrm{SP}$ 振幅・SP/AP 比\%については圧負荷前のレベルよ り大きくなる現象 (Rebound 現象と仮称)を 9 例中 3 例 (33\%)に認めた(表 1). 代表例 (+300 及び $+500 \mathrm{mmH}_{2} \mathrm{O}$ 負荷)を図 6 打よび図 7 に示す。このような Rebound 現象は中耳陰圧負荷群 $\left(-300 \mathrm{mmH}_{2} \mathrm{O}\right)$ 及び外・中耳陽 ・陰圧負荷群 $\left( \pm 300 \mathrm{mmH}_{2} \mathrm{O}\right)$ では認められなかった.

\section{考察}

中耳圧変化が単独に生じた場合について, McPherson ら ${ }^{11)}$ はモルモットの実験において陽・陰圧負荷間で は陰圧負荷の方が $\mathrm{CM}$ の反応低下が大きい傾向にある

表 1 Rebound 現象を認めた中耳陽圧負荷例 $\left(+300 \mathrm{mmH}_{2} \mathrm{O}\right)$ における AP 振幅,

$\mathrm{SP}$ 振幅, SP/AP 比\%の変化

\begin{tabular}{c|c|c|c|c|c|c|c|c|c}
\hline \hline \multirow{2}{*}{ No } & \multicolumn{3}{|c|}{ AP 振幅 $(\mu \mathrm{V})$} & \multicolumn{3}{|c|}{ SP 振幅 $(\mu \mathrm{V})$} & \multicolumn{3}{|c}{ SP/AP 比\% (\%) } \\
\cline { 2 - 10 } & 圧負荷前 & 圧負荷後 & $\begin{array}{c}\text { 圧解除 } \\
\text { 直後 }\end{array}$ & 圧負荷前 & 圧負荷後 & $\begin{array}{c}\text { 圧解除 } \\
\text { 直後 }\end{array}$ & 圧負荷前 & 圧負荷後 & $\begin{array}{c}\text { 圧解除 } \\
\text { 直後 }\end{array}$ \\
\hline (1) & 895 & 832 & 936 & 264 & 205 & 364 & 29 & 25 & 39 \\
\hline (2) & 635 & 572 & 659 & 80 & 70 & 143 & 13 & 12 & 22 \\
\hline (3) & 805 & 705 & 845 & 168 & 91 & 205 & 21 & 13 & 24 \\
\hline
\end{tabular}



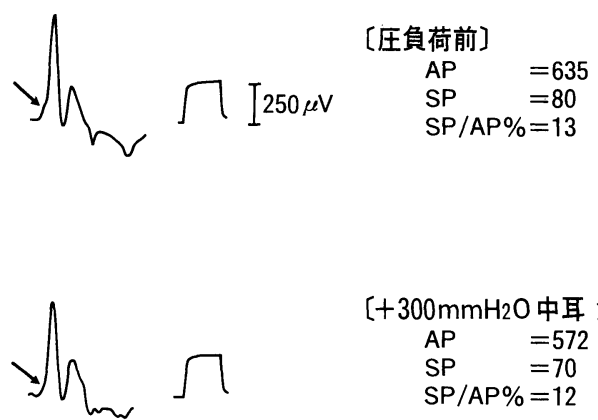

$\begin{aligned} {\left[+300 \mathrm{mmH}_{2} \mathrm{O}\right.} & \left.\text { 中耳 負荷 }\left(50 \mathrm{mmH}_{2} \mathrm{O} / \mathrm{s}\right)\right] \\ \mathrm{AP} & =572 \\ \mathrm{SP} & =70 \\ \mathrm{SP} / \mathrm{AP} \% & =12\end{aligned}$
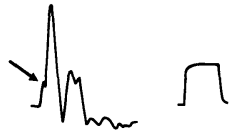

[圧解除直後]

$\begin{array}{ll}\text { AP } & =659 \\ \mathrm{SP} & =143 \\ \mathrm{SP} / \mathrm{AP} \% & =22\end{array}$

図 $6+300 \mathrm{~mm} \mathrm{H}_{2} \mathrm{O}$ 中耳負荷抢よび圧解除時の $\mathrm{SP} \cdot \mathrm{AP}$ 電 位変化 (矢印は SP を示す)
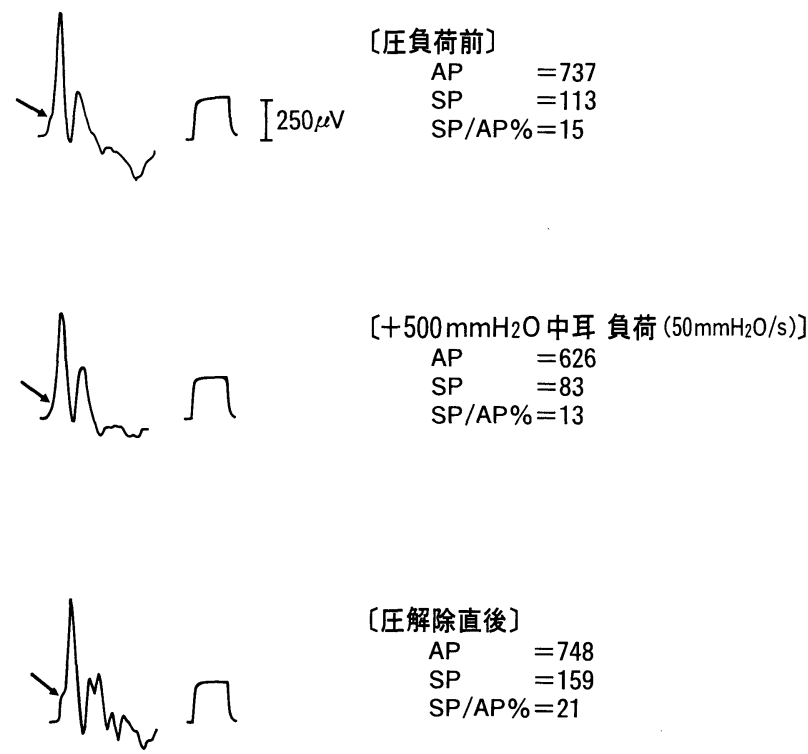

図 $7+500 \mathrm{~mm} \mathrm{H}_{2} \mathrm{O}$ 中耳負荷执よび圧解除時の $\mathrm{SP} \cdot \mathrm{AP}$ 電 位変化(矢印は SP を示す)

ことを認め，これは陰圧負荷の方が陽圧負荷より中耳の インピーダンスとトランスミッションに対して大きな影 響を与えるためであると述べている。本研究に打いて蝸 牛神経の複合活動電位の大きさを示す AP 振幅を聴力変 化の指標とするならば，中耳陽・陰圧負荷間に招いて聴
力低下の程度に有意な差はなかったが陰圧負荷時の方が より大きな聴力低下傾向を認め, やはり陽圧負荷と陰圧 負荷とでは中耳のインピーダンス拉よびトランスミッシ ョンに対する影響の異なることが示唆された。

また外耳圧と中耳圧が同時に変化した場合について， Rahm ら ${ }^{12)}$ はネコに和いて陽・陰圧負荷時に, Ohmura ら13) はモルモットに拈いて陰圧負荷時にそれぞれ CM の反応低下を認めているが，本研究では外・中耳同時圧 負荷に执いて陰圧負荷の方が陽圧負荷上り AP 振幅減少 がやや大きい傾向を認めたが，陽・陰圧負荷間に有意な 差は認められなかった。これは $\mathrm{AP}$ 振幅が蝸牛全回転の 活動状態を総合的に示していることに加えて本研究にお ける圧負荷の大ささが比較的小さい $\left( \pm 300 \mathrm{mmH}_{2} \mathrm{O}\right)$ こ とによると思われるが，いずれにしてもこの程度の小さ な中耳圧変化では外・中耳間の圧均衡が保たれている限 り聴力そのものにはあまり影響を及洼さないと思われる。

さて, 中耳圧変化が単独に生じた場合の聴覚路に生じ る変化は Wever ら ${ }^{910)} \cdot \mathrm{McPherson} ら^{11)}$ によると次の 3つが考えられる。

（1）(鼓膜・耳小骨を含む)中耳インピーダンスの変化

(2) 内耳空 stiffness の增加

(3) 内耳への影響

これらの要因が $\mathrm{SP} \cdot \mathrm{AP}$ 複合波形に及ぼす変化につ いて以下考察する.

一般に，中耳インピーダンスは次式のように表わされ $ろ^{20)}$.

$$
\begin{aligned}
& Z=\sqrt{\mathrm{R}^{2}+\left(\frac{\mathrm{S}}{2 \pi \mathrm{f}}-2 \pi \mathrm{fM}\right)^{2}} \\
& \mathrm{Z}: \text { impedance, } \mathrm{R}: \text { resistance } \\
& \mathrm{S}: \text { stiffness, } \mathrm{M}: \text { mass } \\
& \mathrm{f}: \text { frequency }
\end{aligned}
$$

中耳圧変化が生じると鼓膜和よび耳小骨の stiffness が増加するため中耳インピーダンスは増加する. その結 果として外界から内耳伝達される音響エネルギーが減 少し， SP 执よび AP の振幅は共汪減少するはずである. 実際, 本研究の結果飞执いても中耳圧変化(陽・陰圧と も)によって AP 振幅の減少を認めたが, SP 振幅につ いては陰圧負荷によって増加する例を認め, また中耳イ ンピーダンスの変化の影響を除いた外・中耳同時陰圧負 荷によって SP 振幅の減少を認めた。 この SP 振幅の変 化については中耳インピーダンスの変化のみでは説明が 
つかない.

第 2 に内耳空 stiffness についてであるが，Wever $5^{9) 10)} \cdot$ McPherson $5^{11)} \cdot$ Ohmura ら ${ }^{13)}$ の述べているよ らに内耳空 stiffness の増加によって CM の反応低下が 生じるのであれば，同じ内耳有毛細胞起源の receptor potential と思われる SP の反応低下も生じる可能性が ある.これについて本研究の(中耳インピーダンスの変 化の影響を除いた)外・中耳同時圧負荷時の結果を見て みると，陽圧負荷では SP 振幅の有意な変化はなく陰圧 負荷に扣いて有意な減少を認めた。 Ivarsson ら 21$)$ は, ヒト側頭骨で上半規管に瘻孔をつくった上で外耳・中耳 扣よび正円空等に圧負荷を加えたときの外リンパ液流動 量を測定することによって正円空・卵円空の可動性を調 べたが，その結果両内耳空とも陽圧負荷時と陰圧負荷時 の間に可動性の差はなかったと報告している. しかし， ヒトとモルモットでは蝸牛水管の疎通性が異なる22) 25) ため外リンパ流動の様式も異なる可能性があり, Ohmura ら13)の報告とあわせてみてもやはり陽圧・陰圧負荷間 では内耳空 stiffness の変化が異なるためSP振幅括よ び SP/AP 比\%の変化に差がでたものと思われる.

第 3 に内耳への影響であるが，これについては以前よ り内耳圧変化の観点より比較的多くの報告がある. 中耳 圧変化時の内耳圧変化について, Densert ら 26 はネコの 実験に括いて中耳圧負荷時の外リンパ圧変化量は陰圧負 荷時より陽圧負荷時の方が大きく圧解除時の外リンパ圧 減衰速度は陰圧負荷時の方が大さいことより蝸牛水管に は一方向性の開放性が存在すると述べ, Carlborg 5 27) がこれを確認している. Gyo ら 28$) \cdot$ 西原ら 29)30) ・ 鈴木 ${ }^{31)}$ も同様の報告をして括り，中耳陽圧負荷の方が陰圧負荷 より内耳への影響が大きいものと思われる。このように 中耳圧変化時に内耳圧変化が生じるのであれば内耳圧変 化による電気生理学的影響を考慮せねばならない.内耳 への直接圧負荷実験として Allen ら ${ }^{32)}$ はネコの蝸牛鼓 室階にリンゲル液注入加圧負荷を行なった時 $\mathrm{CM}$ の反 応低下を認め，これは短時間圧負荷 $(5 \sim 10$ 分間)では内 耳伝音系 stiffness 増加, 長時間圧負荷 (1 時間)では内 耳循環障害拉よび有毛細胞障害がその原因であると述べ ている. Butler ら33) はモルモットを用いて蝸牛前庭階 または鼓室階にリンゲル液注入加圧負荷を行なった時, - SP 振幅㐨よび EP 振幅は前庭階加圧にて増加, 鼓室 階加圧にて減少し， CM 及び $\mathrm{AP}$ の変化は軽微であった と報告している．竹田 ${ }^{34)}$ はモルモットを用いて蝸牛鼓
室階に外リンパ等価液によって加減圧負荷を与えたとき の SP・AP 複合電位を記録し，加圧負荷時には SP 振 幅は減少し圧負荷解除にて overshoot 現象がみられたこ とより, SP の変化は外リンパ圧変化による基底膜変位 および内耳循環障害・内耳液組成変化等によって生じた ものと推察している. 以上のことより本研究の結果を考 察してみると，APについては中耳圧負荷に和ける変化 が外・中耳同時圧負荷によってなくなることより内耳圧 変化の影響は Butler ら ${ }^{33)}$ の報告同様軽微であると思わ れる．SPについては，中耳陰圧負荷に拈いて SP 振幅 増加を認める例があることより蝸牛水管の疎通性の個体 差による内耳王変化の多様性がらかがわれる。 しかし外 ・中耳同時圧負荷の結果に拈いて，前述の報告例のよう に中耳圧変化時には陽圧負荷の方が陰圧負荷より内耳へ の影響が大きいのであれば SP の変化は陽圧負荷の方が 大きいはずであるが，実際には陰圧負荷に拈いてのみ変 化を認めることより内耳圧変化よりもむしろ上述のよう に内耳空 stiffness の変化による影響が大であると思わ れる。ただ，中耳陽圧負荷に拈いて圧負荷解除時に SP の Rebound 現象を認めたことより，竹田 ${ }^{34)}$ の報告のよ らに内耳圧変化による二次的な影響の存在も否定できな いものと思われる.

最後に，このような中耳圧変化の臨床蝸電図に和ける 意義について考えてみる。臨床蝸電図に拉ける SP ・ $\mathrm{AP}$ 複合波形はメニエール病をはじめとする内耳疾患の 診断に拈いて重要な役割を果たし, 内リンパ水腫が存在 すると SP/AP 比の増加が認められる35) 38). Ferraro ら ${ }^{19)}$ は正常人において外耳圧負荷を与えた時のSP・ $\mathrm{AP}$ 複合波形を鼓室外誘導にて記録したところ, 陽・陰 圧負荷によって共に SP/AP 比の有意な増加を認め, 中 耳圧変化が内耳の流体力学的または機械一電気変換的な 性質を変化させている可能性があるとし, SP/AP 比を 解釈する際には中耳圧の役割も考慮に入れねばならない と述べている。本研究に打ける SP/AP 比の変化とはヒ トとモルモット，外耳圧負荷と中耳圧負荷等の条件の差 があるため単純に比較はできないが，いずれにしても中 耳圧変化により臨床蝸電図の波形はかなり修飾されてい ると思われる. 特に本研究での中耳陰圧負荷に括いては 上述の 3 つの要因が複雑に作用し蝸電図波形を修飾して いるが，SP 振幅低下が認められる場合が多く，中耳陰 圧存在下では内リンパ水腫が存在しても SP/AP 比の増 加が過小評価される可能性がある.メニエール病症例の 
中には耳管狭窄を合併するものが比較的多いといら報 告39) 女あり, 内リンパ水腫存在下に拈ける中耳圧変化 の蝸電図波形に及ぼす变化については今後更に検討を要 するが，メニエール病の診断に際しては中耳圧変化の影 響の可能性も考慮に入れて SP/AP 比を評価すべきであ ると思われる。

\section{総 括}

中耳圧変化の聴覚和よび蝸電図波形に及ぼす影響を調 ベるために，正常モルモットを用いて中耳抽よ゙外・中 耳に圧負荷を与えた時の蝸電図を記録し，波形の変化拉 よびそのメカニズムについて検討した。

1) AP 振幅については，中耳王負荷に拈いて陽・陰 圧負荷共に有意な減少を認めたが，陽・陰圧負荷間では 有意な差を認めなかった。 また，外・中耳圧負荷に执い て陽・陰圧負荷共に有意な減少を認めなかった。

2) SP 振幅及び SP/AP 比\%については，中耳圧負 荷に拉いて陽圧負荷で有意な減少を認めた。陰圧負荷で はバラツキが大きく有意な差を認めなかったが，これは 蝸牛水管の疎通性の個体差による内耳圧変化の多様性の ためと思われた。 また，外・中耳圧負荷に扣いて陰圧負 荷では陽圧負荷より有意な減少を認め, 陽・陰圧負荷間 で内耳空 stiffness の変化の差がらかがわれた.

3 ）中耳陽圧負荷に括いて，圧負荷解除時に SP 振幅 及び SP/AP 比\%の Rebound 現象が一部で認められ， 内耳圧変化による二次的な影響の可能性がらかがわれた。

4 ）以上の結果より，中耳圧変化によって SP・AP 複合波形の変化が生じることが示唆され, 内リンパ水腫 存在の有無診断の際, 中耳圧変化による臨床蝸電図の修 飾の可能性を考慮に入れた上で，SP/AP 比を評価すべ きであると思われた。

\section{謝辞}

稿を終わるに臨み御懇篤なる御校閲を賜った北嶋和智教授に 深謝致します。また，研究の機会を与兄ていただいた北原正章 名誉教授, ならびに御助言をいただいた教室員の皆様に感謝致 します.

本論文の要旨は第39回日本聴覚医学会総会(つくば市)にて発 表した.

\section{参考文献}

1 ) 柳田則之 : 内耳気圧性外傷の基礎と臨床. 耳鼻臨床 補 3 : $20 \sim 32,1986$.
2 ) 大久保仁, 寺邑公子, 小山澄子, 他 : 潜水 (スクーパ)事故 と耳管機能について. 耳喉 $59:$ 573 578, 1987.

3 ）西原信成, 河村裕二, 暁 清文, 他: 航空性外リンパ瘦例. 耳鼻臨床 $82: 1233 \sim 1237,1989$.

4 ）菊守 寬, 久保 武, 肥塚 泉, 他：航空機搭乗により混 合性難聴を来した症例。耳鼻臨床 $83: 1349 \sim 1354,1990$.

5 ）千田忠男, 上畑鉄之丞: 新幹線列車乗務員室に扣ける気圧 変化と耳症状について. 杏林医会誌 13：461〜 466, 1982.

6 ) Fowler EP : Drum tension and middle ear air pressures ; their determination, significance and effect upon the hearing. Ann Otol Rhinol Laryngol 29 : 688 694, 1920.

7 ) Loch WE : Effect of experimentally altered air pressure in the middle ear on hearing acuity in man. Ann Otol Rhinol Laryngol 51 : 995 1006, 1942.

8 ) Kobrak $\mathrm{H}$ : Influence of the middle ear on labyrinthine prssure. Arch Otolaryngol 21 : 547 560, 1935.

9 ) Wever EG, Bray CW and Lawrence $\mathrm{M}$ : The effects of pressure in the middle ear. J Exp Psychol $30: 40 \sim 52,1942$.

10) Wever EG, Lawrence $M$ and Smith KR : The effects of negative air pressure in the middle ear. Ann Otol Rhinol Laryngol 57 : 418 428, 1948.

11) McPherson DL, Miller JM and Axelsson A : Middle ear pressure ; effects on the auditory periphery. J Acoust Soc Am $59:$ 135 142, 1976.

12) Rahm WE, Strother WF, Lucchina G, et al : The effects of air pressure on the ear. Ann Otol Rhinol Laryngol 67 : 170 $\sim 177,1958$.

13) Ohmura $M$, Satoh $H$ and Honjo I : Influence of altered middle ear pressure on cochlear microphonics. Acta Otolaryngol (Stockh) $104: 255 \sim 260,1987$.

14）内藤 泰, 八木伸也, 伊藤壽一, 他 : 中耳圧の体平衡に拉 よぼす影響. Equilibrium Res 45 : 364〜367, 1986.

15）鈴木幹男，北原正章：中耳圧変化による前庭反射一足踏 み検査を指標として一. Equilibrium Res Suppl 4：81〜83, 1988.

16) Nadol JB Jr : Positive Hennebert's sign in Meniere's disease. Arch Otolaryngol $103: 524 \sim 530,1977$.

17）馬場完仁，坂田英治，大都京子 : 瘦孔症状の臨床診断学的 意義に関する研究一その 1 : 中耳炎, 先天性梅毒に次ぐ 第 3 の意義一. 耳鼻臨床 $79: 1573 \sim 1580,1986$.

18) Hennebert $C: A$ new syndrome in her editary syphilis of the labyrinth. Presse Med Belg Brux $63: 467 \sim 470,1911$.

19) Ferraro JA, Nunes $R R$ and Arenberg IK : Electrocochleographic effects of ear canal pressure change. Am J Otol $10:$ 42 48, 1989.

20) Gelfand SA : Hearing ; An Introduction to Psychological and Physiological Acoustics, 2nd Edition. pp 36 38, Marcel Dekker, New York, 1990. 
21) Ivarsson $A$ and Pedersen $K$ : Volumepressure properties of round and oval windows; a quantitative study on human temporal bone. Acta Otolaryngol (Stockh) $84: 38$ $\sim 43,1977$.

22) Ritter FN and Lawrence $M$ : A histological and experimental study of cochlear aqueduct patency in the adult human. Laryngoscope $75:$ 1224 1233, 1965.

23) Palva $T$ and Dammert $K:$ Human cochlear aqueduct. Acta Otolaryngol Suppl (Stockh) $246: 1 \sim 57,1969$.

24) Sando I, Wood II RP, Masuda $Y$, et al : Perilymphatic communication routes in guinea pig cochlea. Ann Otol Rhinol Laryngol $80: 826 \sim 834,1971$.

25) Moscovitch DH, Gannon RP and Laszlo CA : Perilymph displacement by cere brospinal fluid in the cochlea. Ann Otol Rhinol Laryngol $82: 53 \sim 61,1973$.

26) Densert O, Carlborg B and Stagg J : Transmission of low frequency pressure steps to the perilymphatic fluid. Acta Otolaryngol (Stockh) $91: 55 \sim 64,1981$.

27) Carlborg B, Densert B and Densert O : Functional patency of the cochlear aqueduct. Ann Otol $91: 209 \sim 215,1982$.

28) Gyo K, Nishihara S and Yanagihara N : Pressure transmission properties from the external ear canal to the inner ear. Acta Otolaryngol Suppl (Stockh) $456: 87 \sim 91,1988$.

29）西原信成, 暁 清文, 柳原尚明: 外耳圧の内耳への伝達に 関する研究. 耳鼻臨床 $81: 1339 \sim 1344,1988$.

30）西原信成：外耳圧の内耳への伝達機序に関する実験的研究. 日耳鼻 $93: 707 \sim 715,1990$.

31）鈴木幹男：中耳压の前庭機能に及ぼす影響. 耳鼻臨床 補 $55: 1 \sim 27,1992$.
32) Allen GW, Dallos P, Sakamoto S, et al : Cochlear microphonic potential in cats; effects of perilymphatic pressure. Arch Otolaryngol 93 : 388 396, 1971.

33) Butler RA and Honrubia V : Responses of cochlear potentials to changes in hydrostatic pressure. J Acoust Soc Am $35:$ 1188 1192, 1963.

34）竹田泰三 : メニエール病の聴覚に関する実験的研究. 耳鼻 臨床 $74: 2507 \sim 2561,1981$.

35) Schmidt PH, Eggermont JJ and Odenthal DW : Study of Meniere's disease by electrocochleography. Acta Otolaryngol Suppl $316: 75 \sim 84,1974$.

36) Gibson WPR, Moffat DA, and Ramsden RT : Clinical electrocochleography in the diagnosis and management of Meniere's disorder. Audiology $16: 389 \sim 401,1977$.

37) Kitahara M, Takeda T, Yazawa Y, et al : Electrocochleography in the diagnosis of Meniere's disease. Meniere's Disease; Pathogenesis, Diagnosis and Treatment (ed by Vosteen KH, Schuknecht H, Pfaltz CR, et al). pp 163 169, Thieme-Stratton Inc, New York, 1981.

38) Coats AC: The summating potential and Meniere's disease. Arch Otolaryngol $107:$ 199 208, 1981.

39) Hall CM and Brackmann DE : Eustachian tube blockage and Meniere's disease. Arch Otolaryngol $103: 355 \sim 357$, 1977.

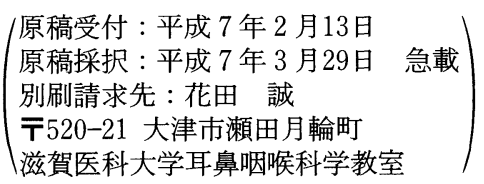

